\begin{tabular}{|l|l|l||}
\hline \multicolumn{2}{|c|}{ PublisherInfo } \\
\hline \hline PublisherName & $:$ & BioMed Central \\
\hline \hline PublisherLocation & $:$ & London \\
\hline \hline PublisherImprintName & $:$ & BioMed Central \\
\hline \hline
\end{tabular}

\title{
Antisense RNA
}

\begin{tabular}{|l|l|l||}
\hline \multicolumn{2}{|c|}{ ArticleInfo } \\
\hline \hline ArticleID & $:$ & 4385 \\
\hline \hline ArticleDOI & $:$ & $10.1186 /$ gb-spotlight-20020125-01 \\
\hline \hline ArticleCitationID & $:$ & spotlight-20020125-01 \\
\hline \hline ArticleSequenceNumber & $:$ & 51 \\
\hline \hline ArticleCategory & $:$ & Research news \\
\hline ArticleFirstPage & $:$ & 1 \\
\hline \hline ArticleLastPage & $:$ & 2 \\
\hline \hline & & RegistrationDate : 2002-1-25 \\
\hline ArticleHistory & $:$ & OnlineDate \\
\hline \hline ArticleCopyright & $:$ & BioMed Central Ltd2002-1-25 \\
\hline \hline ArticleGrants & $:$ & \\
\hline \hline ArticleContext & $:$ & 130593311 \\
\hline \hline
\end{tabular}




\section{Jonathan B Weitzman}

Email: jonathanweitzman@hotmail.com

Gene silencing by RNA interference (RNAi) has become a powerful tool for functional genomics. In the January 25 Science, Tijsterman et al. report a gene-silencing method induced by short ( 25 nucleotide) antisense RNA molecules (Science 2002, 295:694-697). They found that injecting singlestranded, antisense RNA (asRNA) oligomers into the gonadal syncytium of Caenorhabditis elegans resulted in silencing of the maternal pos-1 gene and of germline-expressed genes. Tijsterman et al. found that asRNA silencing requires the mutator/RNAi genes mut-7 and mut-14. They cloned the mut-14 gene and report that it encodes a putative RNA helicase with a DEAD-box motif. The authors propose that asRNA-induced gene-silencing may result from the priming of RNA synthesis on mRNA templates, thereby creating dsRNA for subsequent degradation.

\section{References}

1. Functional anatomy of a dsRNA trigger: differential requirement for the two trigger strands in RNA interference.

2. Science, [http://www.sciencemag.org] 